\title{
Obituaries
}

\section{Marcel Haegi}

Scientist who became a leading international road safety campaigner

Marcel Haegi was a renowned nuclear physicist. But what resonates for me, and for the $B M J$-at a time when 3000 deaths every day on the world's roads is accepted as the necessary albeit regrettable cost of motorised transportation-is Marcel's contribution as a road safety activist and advocate for justice for those injured and killed.

In 1988 Marcel's eldest daughter, Vlasta, died when her car was struck by a speeding driver, who survived, was prosecuted, and was required to pay compensation. Marcel and his family were expected to suffer in silence just like the thousands of other parents who have lost children to road traffic crashes.

The state's response to road death is unlike any other form of violent death. There is rarely a proper police investigation, the judicial response is characteristically lackadaisical, and little effort is made to prevent a recurrence. Given the numbers killed and injured each year-over 50000 deaths and 150000 permanent disabilities in Europe alone-road death might be thought of as state sanctioned genocide. In many countries, Britain included, road deaths are called "accidents." No one is really responsible and no one is really to blame. Marcel, however, could not accept this.

In their fight for justice, those injured on the roads had recruited a formidable ally. Marcel was a scientist, a statesman, and extraordinarily tenacious. He obtained a doctorate in physics at the University of Geneva in 1968. He worked for several years as a research assistant at the European Centre for Nuclear Physics (CERN) before taking up the post of principal researcher at the Italian Centre for Nuclear Research in Frascati, Italy. He went on to become scientific adviser at the European Commission. By the time he retired in 1996, he had published close to 100 papers on experimental and theoretical physics.

Following the death of his daughter, Marcel founded the Association des Familles des Victimes de la Route in Switzerland. His aim was to give a voice to people killed or injured on the roads. Marcel was an experienced diplomat and he understood that in order to have political influence at the level of the major inter-

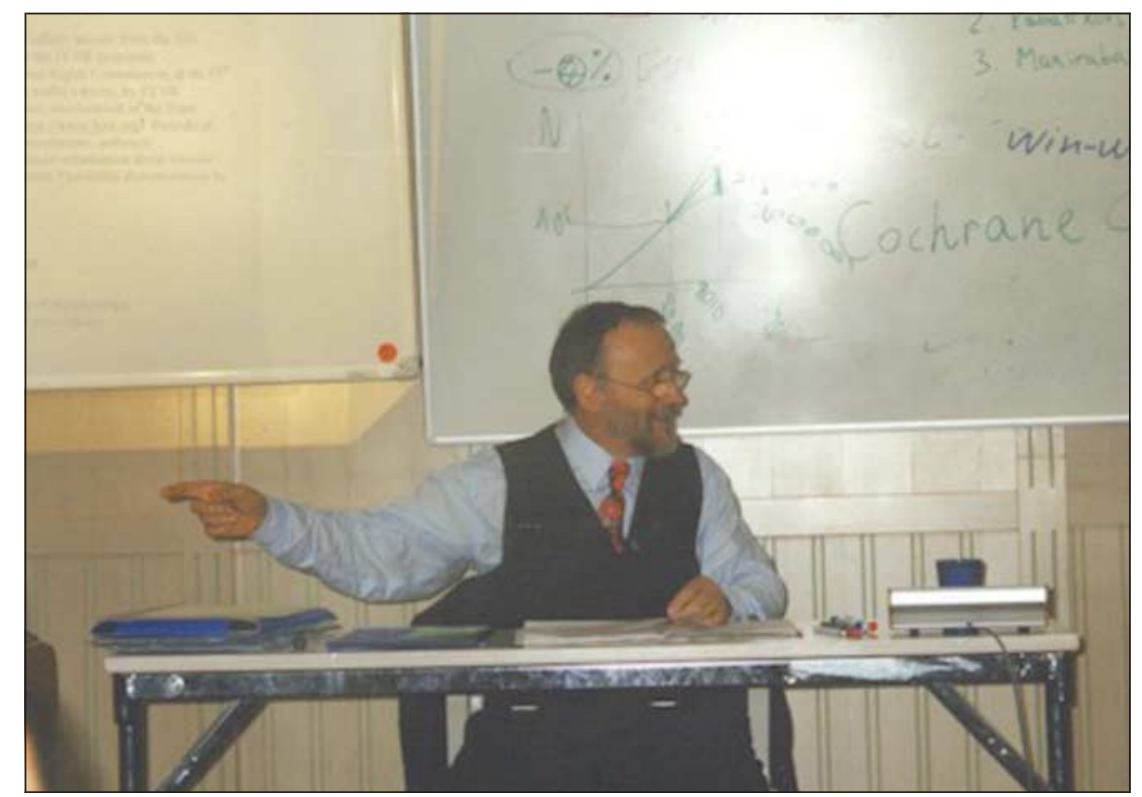

national institutions he needed to forge a broad based coalition of national organisations. He set about this with vigour and ability and by 1991 he had founded the European Federation of Road Traffic Victims. The organisation grew rapidly. In 1993 the federation comprised just five national organisations, but 10 years later there were 35 organisations from across Europe. The federation was by then the largest road injuries organisation in the world.

In 1997 the federation gained consultative status at the United Nations. This was a major coup since it meant representation on the various UN road safety and human rights related working parties. Although the federation could not vote, this was an opportunity to put road injuries issues on the agenda and to lobby the national representatives. Gaining consultative status was not an easy victory. Britain and Germany voted against the proposal and Marcel said that had it not been for the African states the application would have failed.

After retiring, Marcel became a full time road safety and road injuries advocate. $\mathrm{He}$ regularly attended UN meetings in Geneva (at his own expense), published a monthly newsletter, represented those killed and injured on the steering committee of the Medical Research Council CRASH trial, helped to edit the $B M J$ theme issue on road crashes (11 May 2002), and served on the working group on interventions for the World Report on Road Traffic Injury Prevention. He was driven by passion but a passion constrained by reason. He felt that 2004 would be an important year for the federation. For the first time World Health Day had been dedicated to road safety, the UN had announced Road Safety Week, and this week would see the launch of the World Report on Road Traffic Injury Prevention. It is therefore particularly tragic that he will not see for himself how the ripples of roads, which he had been so active in initiating, are now gaining momentum and rising into waves.

He leaves a wife, Sybille, and his children. [IAN RoBERTS]

Marcel Haegi, road safety campaigner and nuclear physicist (b 1931), died from prostate cancer on 6 February 2004. indignation against the slaughter on the 


\title{
Philip Andrew Banks Raffle
}

\author{
Occupational physician who wrote Medical Aspects of Fitness to Drive
}

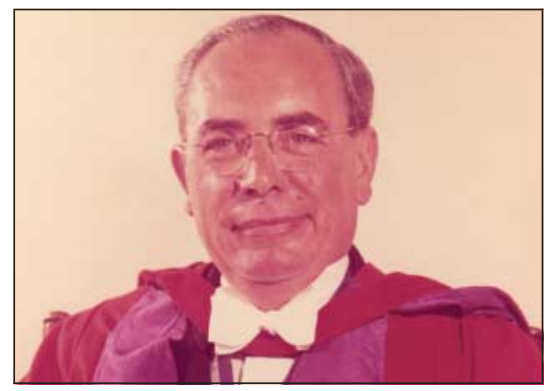

Andrew Raffle was an acknowledged expert on medical standards for driving both motor vehicles and trains. He advised the Department of Transport and other organisations on safe levels of alcohol in blood, and on the effects of diabetes and various medications. $\mathrm{He}$ was a member of the Blennerhasset Committee on drinking and driving legislation and he wrote numerous papers for the medical and lay press on health standards for drivers.

He wrote Medical Aspects of Fitness to Drive and revised it in 1985 , when it was published by the Medical Commission on Accident Prevention, of which Andrew was chairman; this booklet has become the standard reference for all doctors who are called upon to assess a person's fitness to drive, and is frequently updated.

\section{Roy Frank Goulston}

Former general practitioner Sydney, Australia, and Brixton, London (b Sydney, Australia, 1923; q Sydney 1951; FRCGP), died from prostate cancer on 10 January 2004.

During the second world war Roy served in the Australian artillery in the Pacific theatre. $\mathrm{He}$ was in practice in Sydney for 16 years before moving to London in 1970. He served on the local medical committee and the district management team of St Thomas's Hospital, and was an associate regional adviser. For many years he was a tutor on the GP trainers' course. He enjoyed surfing and Australia's frequent sporting successes. He leaves a wife, Simone; four children; and 11 grandchildren. [ALAN Ruben, Richard Savage]

\section{Bernard Leo Hoffmann}

Former ophthalmologist southern Rhodesia (b 1917; q Manchester 1943; DOMS), died from oesophageal cancer on 15 February 2004. After hospital posts in Manchester Bernard joined the Royal Army Medical Corps and served in north Africa and Italy. He was mentioned in dispatches. After war service he worked at the Manchester Royal Eye Hospital. He went to work in southern Rhodesia in 1950 , where he provided an effective single-
After qualifying in 1941, Andrew served for five years as a major in the Royal Army Medical Corps, becoming a medical specialist venereologist in Egypt during the north African campaign. Opting for a career in occupational medicine after demobilisation, he joined London Transport in 1948, becoming chief medical officer in 1969.

While providing occupational health care to thousands of transport workers, Andrew researched the comprehensive records of sickness absence in both underground and bus workers, where he found epidemiological evidence of the relationship between exercise and heart disease by comparing the health of drivers and conductors.

Andrew taught first aid and organised many competitions, and he helped to rewrite the Red Cross/St John first aid manual. He took an active part in the organisation of the St John Ambulance Association, for which he was awarded the knighthood of St John.

In 1984 he instigated the Save-a-Life Campaign to educate the public in emergency resuscitation; this was run jointly by the Royal Society of Medicine, of which Andrew was then honorary secretary, and the St John, of which he was then chief medical officer. BBC television produced seven 10-minute programmes

handed ophthalmic service until he retired in 2001 after 58 years. He was awarded a papal knighthood of Saint Gregory in 1966. Predeceased by his wife, Kathleen, he leaves six children. [BERNARD V LEE]

\section{William Sim Munro}

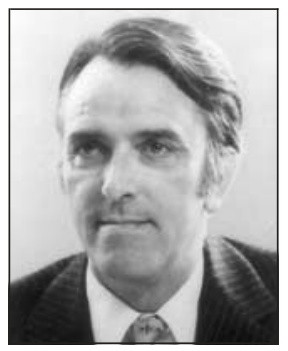

Former medical director, regional medical officer, and consultant Sussex (b Renfrew, Scotland, 1929; $q$ Edinburgh 1952;DTMEH, DPH, DIH), died 28 December 2003.

In 1953, after house jobs in Edinburgh, Bill left for Malaya, where he worked in preventive medicine and as a government adviser for 15 years. On his return to the United Kingdom he worked for the Scottish Home and Health Department and as deputy principal medical adviser, Livingstone New Town, before turning to the pharmaceutical and 135000 people were trained at centres around the United Kingdom. Many lives continue to be saved as a result of this initiative.

He wrote a number of chapters in medical textbooks and in 1994 co-edited the standard textbook Hunter's Diseases of Occupation.

At the BMA he became deputy chairman of the occupational health committee and his long service to the BMA was rewarded by his election to a fellowship. $\mathrm{He}$ also served the Society of Occupational Medicine in many roles, becoming president in 1967.

As honorary treasurer of the Royal Society of Medicine from 1976 to 1982, he masterminded the purchase of the old Post Office building in London's Wimpole Street and laid the foundations for the RSM's present prestigious headquarters. He later became vice president and an honorary fellow-a rare honour.

He leaves a wife, Jill. [W M Drxon, J L KEARNS]

Andrew Raffle, former chief medical officer London Transport Executive (b Newcastle upon Tyne 1918; q Middlesex Hospital 1941; OBE, $M D, F R C P, F R C S)$, died from heart failure on 23 January 2004.

industry. For nine years he was a regional medical officer for the Post Office. After retirement in 1989 he set up a charity, SALT (Stress and Life Trust), advising the employees of large corporations on how to deal with stress. Predeceased by his first wife, he leaves his second wife, four children, and two grandchildren. [RANALD T I MUNRo]

\section{Nicholas Mark Alma Oakman}

Staff grade anaesthetist King's Lynn, Norfolk (b 1959; q Westminster Hospital 1985; DA), d 27 February 2004.

Nick trained as a houseman in King's Lynn, before moving to Chase Farm Hospital, where he took a post in pathology. He had cystic fibrosis and in 1989 his health had deteriorated to such an extent that he required a heart/lung transplant. Following a long recovery period Nick returned to King's Lynn to commence a career in anaesthetics. It was as an administrator and negotiator that he found his true niche. He ran the complex departmental and theatre scheduling rotas with consummate skill. A staunch Christian, he became one of the longest surviving heart/lung recipients. He leaves a wife, Anne Marie. [SIMON HARRIS]

Longer versions of these obituaries are available on bmj.com 